\title{
Bacterial distribution and activity at the water-sediment boundary layer on NW Mediterranean continental margin
}

\author{
Olivier Tholosan, Armand Bianchi* \\ Microbiologie Marine (C.N.R.S. - I.N.S.U., UPR 223), Université de la Méditerranée-Campus de Luminy, Case 907, \\ F-13288 Marseille cedex 9, France
}

\begin{abstract}
We studied the distribution of bacterial populations and their catabolic activities $\left[{ }^{14} \mathrm{C}\right.$-glutamate respiration and Leu-MCA (L-leucine-7-amido-4-methyl-coumarin hydrochloride) hydrolysis] in a set of samples collected in the near bottom waters and in the superficial sediments (0 to $41 \mathrm{~cm}$ depth) originating from 9 cores collected between 585 and $2065 \mathrm{~m}$ depth in diverse NW Mediterranean continental margins. Bacterial densities and respiration rates in the sediment generally exceeded counts and rates in the near bottom water by 4 orders of magnitude. The relative contributions of benthic and pelagic bacteria to the organic matter turnover in this oceanic area are discussed. Data showed that the highest bacterial densities, as well as the highest rates of glutamate mineralization, were usually in the most superficial layers of sediment, whereas proteolysis rates were frequently maximal nearly $5 \mathrm{~cm}$ deeper. This pattern for proteolysis differs from the decreasing gradient usually described.
\end{abstract}

KEY WORDS: Oceanic margin - Mediterranean Sea Deep sea Sediment - Bacteria Mineralization . Proteolytic activity

\section{INTRODUCTION}

The contribution of microbial populations to the benthic biomass in deep sea sediment (Deming \& Yager 1992, Pfannkuche 1993, Parkes et al. 1994) as well as the role of their activities in the biogeochemical cycling during early diagenesis are widely described (Bensoussan \& Bianchi 1983, Rowe \& Deming 1985, Cahet et al. 1990, Turley \& Lochte 1990, Deming \& Baross 1993, Poremba et al. 1994). A critical point is the actual contribution of deep sea bacterial consortia to the coupling between pelagic and benthic activities (Deming 1985, Deming \& Baross 1993, Poremba 1994, Smith et al. 1994, Poremba \& Hoppe 1995, Turley et al. 1995, Boetius et al. 1996, Ritzrau et al. 1997). Bacterial communities in the upper layer of the ocean act as a filter, rapidly using the labile organic compounds produced by photosynthesis. During their sinking period the

·E-mail: a-bianchi@luminy.univ-mrs.fr small size particles are subject to microbial attack (Deming 1985, Hoppe et al. 1993, Poremba 1994, Turley \& Mackie 1994, Turley et al. 1995). Conversely, the rapidly sinking larger particles or aggregates pass through this biological filter and provide the seafloor with energy-rich material.

In the near bottom waters (i.e. at the end point of their transit through the whole water column) microbial communities linked to the particles have the best opportunity to exhibit their ability to adapt to the degradation of settling material. Turley \& Lochte (1990) showed that the sedimented detrital material can be rapidly degraded in deep sea conditions. Therefore, study of microbial abundance and metabolic activities at the benthic boundary layer is particularly useful for understanding the coupling between pelagic and benthic fluxes of nutrients. Nevertheless, on the continental margins, the quality and quantity of these inputs vary with the water column thickness for vertical flux, and with the distance from the coast and the bathymorphological sites on the slope for the advective 


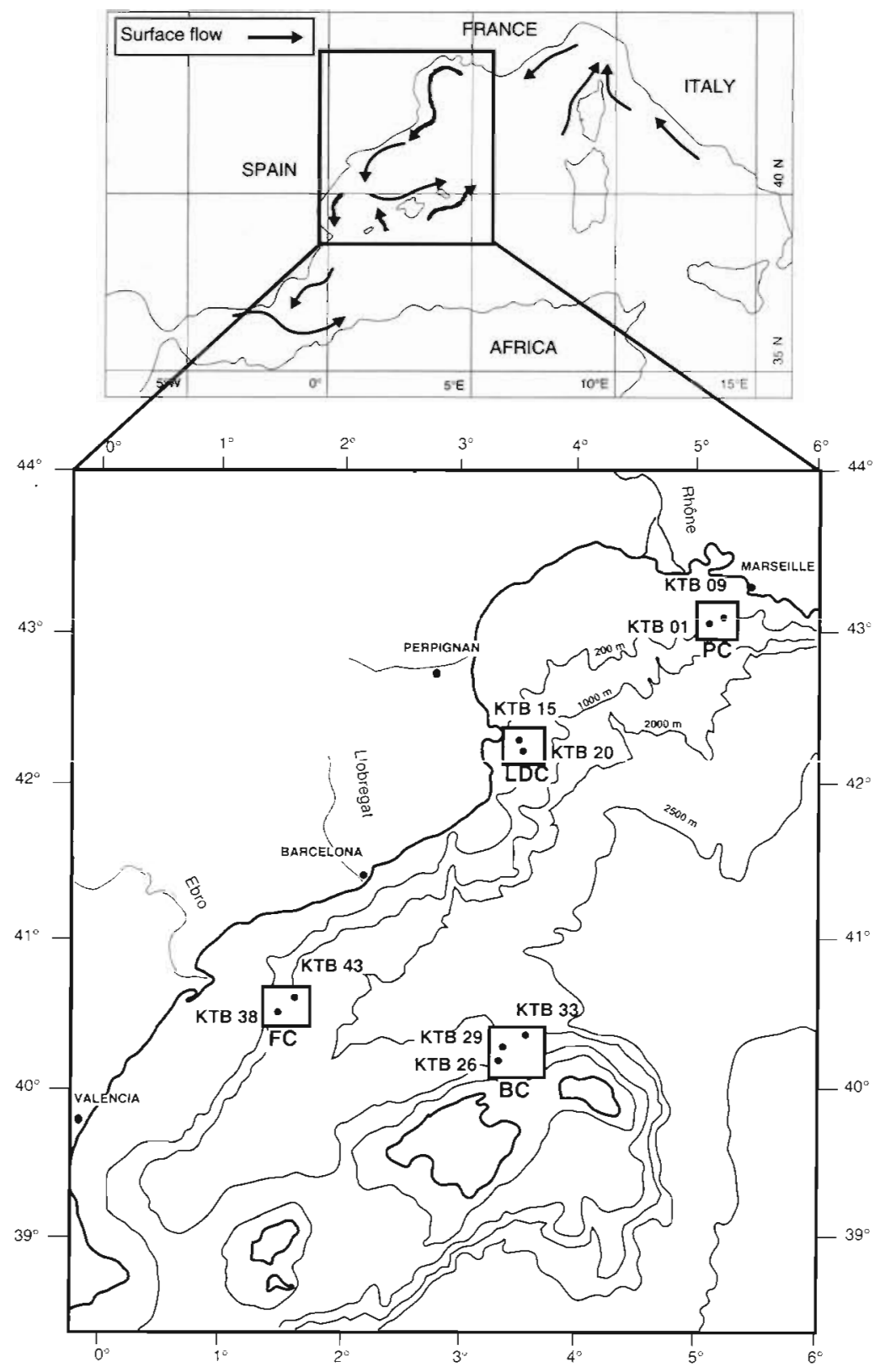

Fig. 1. Northwestern Mediterranean Sea. Location of the 4 sampling zones: Balearic Canyon (BC), Foix Canyon (FC), Lacaze-Duthiers Canyon (LDC), Planier Canyon (PC), and the 9 sampling stations (KTB \#). Insert shows the northwestern Mediterranean Current. (Redrawn from Yoro et a.. 1997)

fluxes. Fluxes are greater in the axial channel of the canyons as compared to adjacent open slopes (Monaco et al. 1990). Consequently, the sedimentation rate and the residence time at the sediment water interface greatly vary in continental margin environments (Buscail \& Germain 1997, Buscail et al. 1997).

In an attempt to determine the role of benthic bacterial communities in the cycling of settling particulate organic matter, we studied the distribution and the cata- bolic activities of bacteria in a set of samples collected in the near bottom waters and in the superficial layers of sediment in diverse deep northwestern Mediterranean continental margins. Most of the organic bulk in the deep sea is composed of high molecular weight polymers (Boetius \& Lochte 1994). These compounds must be hydrolyzed to monomeric compounds before being utilized by heterotrophic bacteria (Chrost 1991, Meyer-Reil 1991). As a consequence, mineralization activity may be considered to depend on the efficiency of macromolecule hydrolysis. The main goal of this study was to estimate the respective roles of aquatic and sedimentary microflora in these 2 steps in the degradation of the oceanic organic matter. The other objective was to quantify the distribution of bacterial biomasses and the degradation processes they can manage throughout the upper $20 \mathrm{~cm}$ thick sediment layer in diverse sedimentary conditions characteristic of Mediterranean continental margins.

\section{MATERIAL AND METHODS}

Study area and sample collection. This study was a part of the EUROMARGE-NB program. The general objective of this program was to estimate the energy and matter flow in the water column and the sediment in different continental margin zones of the northwestern part of the Mediterranean Sea (Canals et al. 1997). Samples were collected in June 1995 during the Euromarge 95 cruise of the RV 'Suroit'. During this cruise 4 zones were investigated: the Balearic Islands Canyon, Foix Canyon, Lacaze-Duthiers Canyon and Planier Canyon (Fig. 1).

In each zone we had 2 sampling sites corresponding to the canyon bottom and to the adjacent open slope. On the Balearic margin the deepest zone, at $2065 \mathrm{~m}$, was sampled (Table 1). Samples were collected using a multiple corer (Barnett et al, 1984). Cores disturbed during retrieval were discarded

The sediments consisted of fine clay, the redox boundary being between 4 and $18 \mathrm{~cm}$ depth (Buscail et al. 1997). Organic composition of the sediment (total and organic carbon, total nitrogen, amino acids and sugar content) in the surface deposits of the NW Mediterranean margin have been described by Buscail \& Germain (1997). 
Table 1. Location and depth of the sampling stations in the northwestern Mediterranean Sea, 5 to 16 June 1995

\begin{tabular}{|llllrr|}
\hline Station & Zone & Location & Latitude & Longitude & Depth (m) \\
\hline KTB 01 & Planier & Canyon axis & $43^{\circ} 00.680^{\prime} \mathrm{N}$ & $05^{\circ} 11.46^{\prime} \mathrm{E}$ & 1150 \\
KTB 09 & Planier & Open slope & $43^{\circ} 00.485^{\prime} \mathrm{N}$ & $05^{\circ} 16.787^{\prime} \mathrm{E}$ & 620 \\
KTB 15 & Lacaze-Duthiers & Canyon axis & $42^{\circ} 26.170^{\prime} \mathrm{N}$ & $03^{\circ} 41.659^{\prime} \mathrm{E}$ & 1175 \\
KTB 20 & Lacaze-Duthiers & Open slope & $42^{\circ} 25.692^{\prime} \mathrm{N}$ & $03^{\circ} 41.997^{\prime} \mathrm{E}$ & 775 \\
KTB 26 & Balearic Islands & Canyon axis & $40^{\circ} 13.090^{\prime} \mathrm{N}$ & $03^{\circ} 25.678^{\prime} \mathrm{E}$ & 1230 \\
KTB 29 & Balearic Islands & Open slope & $40^{\circ} 13.956^{\prime} \mathrm{N}$ & $03^{\circ} 37.040^{\prime} \mathrm{E}$ & 585 \\
KTB 33 & Balearic Islands & Open slope & $40^{\circ} 27.312^{\prime} \mathrm{N}$ & $03^{\circ} 43.381^{\prime} \mathrm{E}$ & 2065 \\
KTB 38 & Foix & Open slope & $40^{\circ} 54.016^{\prime} \mathrm{N}$ & $01^{\circ} 47.218^{\prime} \mathrm{E}$ & 1050 \\
KTB 43 & Foix & Canyon axis & $40^{\circ} 56.733^{\prime} \mathrm{N}$ & $01^{\circ} 54.700^{\prime} \mathrm{E}$ & 1310 \\
\hline
\end{tabular}

Samples were immediately processed on board the research vessel. For each core, the near bottom water (NBW) overlaying the sediment was carefully and aseptically collected by siphoning into a polycarbonate vessel. The last millilitres were discarded to prevent aspiration of mud particles in the seawater samples. The core was then extruded and sliced using sterile cutters. Subsamples were collected in the central part of each sediment slice $(0-0.5,0.5-1,1-2,2-3,3-5$, $5-7,11-12,17-20,40-41 \mathrm{~cm}$ depth) using a $5 \mathrm{ml}$ sterile plastic syringe with the end cut off.

Bacterial counts. Near bottom seawater samples were immediately fixed by adding $0.2 \mu \mathrm{m}$ filtered formaldchyde ( $4 \%$ final concentration). Sediment samples were diluted $(1 / 1: \mathrm{v} / \mathrm{v})$ with filter sterilised seawater and fixed with $0.2 \mu \mathrm{m}$ filtered formaldehyde $(4 \%$ final concentration). Fixed samples were stored for nearly 1 mo at $5^{\circ} \mathrm{C}$ until processing on land. Seawater samples were sonicated during 4 periods of $30 \mathrm{~s}$ separated by 1 min cooling periods, using a Vibra Cell 600 sonic probe equipped with a $5 \mathrm{~mm}$ microtip providing $\sim 45 \mathrm{~W} \mathrm{~cm}^{-2}$. Samples were 4'6-diamidino-2-phenylindole (DAPI) stained, filtered on a black $0.2 \mathrm{~mm}$ Nuclepore filter and bacteria were counted using an epifluorescence microscope (Porter \& Feig 1980). Sediment slurries $(1 / 1, v / v)$ were ultrasonicated as above, diluted 1000 -fold in $0.2 \mu \mathrm{m}$ filtered seawater, sonicated again, and then processed as above.

The bacterial counts were converted to bacterial biomass by using the conversion factor of $20 \times 10^{-15} \mathrm{~g} \mathrm{C}$ cell-1 proposed by Lee \& Fuhrman (1987).

Microbial activity measurements. Ectoproteolytic activity measurements: Protease activity was measured in sediment slurries by using the fluorogenic substrate analog Leu-MCA (L-leucine-7-amido-4-methylcoumarin hydrochloride) (Sigma Chemical Co.) following the protocol described by Talbot \& Bianchi (1997). Sediment slurries were diluted with their own $0.2 \mu \mathrm{m}$ prefiltered near bottom water to a $1 / 4(\mathrm{v} / \mathrm{v})$ final dilution and distributed among sterile polycarbonate tubes ( $1 \mathrm{ml}$ per tube). Substrate was added at $1000 \mu \mathrm{M}$ final concentration. Incubations for time-course experiments were carried out in the dark at in situ temperature $113 \pm$ $1^{\circ} \mathrm{C}$ ). For each sample, 3 tubes were boiled for $30 \mathrm{~min}$ to control abiotic cleavage of Leu-MCA. At the end of each incubation period $(0,30,60$ and $90 \mathrm{~min})$ the tubes were vortexed and then centrifuged $(10 \mathrm{~min}$ at $2180 \times$ g). Fifty $\mu$ l of overlying water was diluted with $3 \mathrm{ml}$ of Milli-Q water. Fluorescence was determined using a spectrofluorometer (Hoefer TKO 100) calibrated using the same protocol, replacing Leu-MCA with standard MCA (7-amino-4-methylcoumarin) in concentrations between 10 and $60 \mu \mathrm{M}$.

Heterotrophic activity measurements. Near bottom waters: A solution of $\mathrm{L}-\left(\mathrm{U}-{ }^{14} \mathrm{C}\right)$-glutamate, specific activity $9.77 \mathrm{GBq} \mathrm{mmol}^{-1}$ (Amersham Corp.), was added to give a final concentration of $10 \mathrm{nM}$. For time course experiments labeled subsamples were incubated in the dark at in situ temperature $\left(13 \pm 1^{\circ} \mathrm{C}\right)$. Subsamples $(20 \mathrm{ml})$ were taken at time zero (control), 60,180 and $360 \mathrm{~min}$. At the end of each incubation period subsamples were fixed by the addition of buffered formalin (1.0\% final concentration, v/v). Bacterial cells were collected by vacuum filtration on $0.2 \mu \mathrm{m}$ polycarbonate filters (Nuclepore) prewashed with an unlabeled glutamate solution. Filters were washed twice with $5 \mathrm{ml}$ of $0.2 \mu \mathrm{m}$ filtered seawater. The filtrate was then acidified $(1 \mathrm{ml} \mathrm{HCl}, 6 \mathrm{~N})$ and released ${ }^{14} \mathrm{C} \mathrm{CO}_{2}$ was flushed by $\mathrm{N}_{2}$ blowing $(100 \mathrm{ml}$ $\mathrm{min}^{-1}$ ) for $10 \mathrm{~min}$. Carbon dioxide was trapped in 2 serial scintillation vials containing a trapping cocktail ethanolamine/methanol/PCS (Complete Phase Counting System, Amersham Corp.) scintillation liquid $(1 / 1 / 7, v / v)$. Labeled carbon on the filters and in the carbon dioxide traps was counted on a Packard 1600 TR liquid scintillation counter. Data were corrected against those from control samples. ${ }^{14} \mathrm{C}$-glutamate incorporation, ${ }^{14} \mathrm{C}$-glutamate respiration, and ${ }^{14} \mathrm{C}$-glutamate utilization rates (sum of incorporated and respired label) and the respiration percentage $(R \%$, percentage of the respired to the total ${ }^{14} \mathrm{C}$-glutamate utilization) were computed from these data. 
Sediment samples: Sediment slurry prepared as above $(1 / 1, v / v)$ was distributed among $15 \mathrm{ml}$ sterile penicillin flasks $(200 \mu \mathrm{l}$ per flask). A solution of $\mathrm{L}-(\mathrm{U}-$ ${ }^{14} \mathrm{C}$ )-glutamate, specific activity $9.77 \mathrm{GBq}_{\mathrm{mmol}}^{-1}$ (Amersham Corp.), was added to give a final concentration of $1 \mu \mathrm{M}$. For each sample, 3 tubes were formaldehyde fixed ( $4 \%$ final concentration) before label addition. Labeled subsamples were incubated as above. At the end of each incubation period $(60,180$ and $360 \mathrm{~min}$ ) 3 culture flasks were fixed by the addition of buffered formalin ( $4 \% \mathrm{v} / \mathrm{v})$. A strip of Whatman paper soaked with ethanolamine as $\mathrm{CO}_{2}$ trapping agent was introduced into the culture flask, then $0.5 \mathrm{ml}$ of $6 \mathrm{~N} \mathrm{HCl}$ was carefully injected through the rubber stopper. Radioactive carbon dioxide trapped on the paper strip was counted as mentioned above.

\section{RESULTS}

\section{Near bottom waters (NBW)}

Bacterial abundance in the NBW ranged from $5.5 \times$ $10^{4}$ cells $\mathrm{ml}^{-1}$ in the Planier open slope, to $29.2 \times 10^{4}$ cells $\mathrm{ml}^{-1}$ in the Foix open slope. The bacterial density

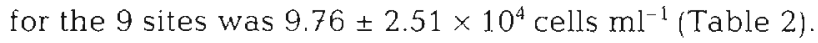

The average utilization rate for ${ }^{14} \mathrm{C}$-glutamate uptake was $35.14 \pm 5.43 \mathrm{pmol} \mathrm{C} \mathrm{I}^{-1} \mathrm{~h}^{-1}(\mathrm{n}=9)$ (Table 2). The 2

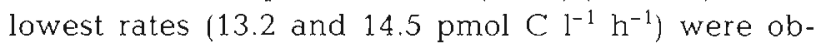
served in the Balearic Islands zone, at the deepest (KTB 33: $2065 \mathrm{~m}$ ) and shallowest sampling sites (KTB 29: 585 $\mathrm{m})$, respectively. The average rates observed in the 5 samples collected from the open slope $(32.1 \pm 9.3, n=5)$ did not significantly differ from those measured in the canyon bottom $(39.6 \pm 4.8, n=4)$. Metabolic rates were higher in the Planier Canyon zone (44.8 and $58.2 \mathrm{pmol}$ $\mathrm{C}^{-1} \mathrm{~h}^{-1}$ in the canyon bottom and the open slope area, respectively) and clearly lower in the Balearic Islands zone (25.1 and 13.6 in the canyon bottom and the open slope area, respectively). Most of the ${ }^{14} \mathrm{C}$-glutamate metabolised by the bacterial communities was used for energy production, as shown by the respiration percentage $R \%=65.1 \pm 3.8(n=9)$. This average value for relatively deep near bottom waters did not differ from the estimation commonly used in the literature (Novitsky 1983). The $R \%$ coefficient was always higher in the open slope than in the canyon bottom (Table 2).

\section{Bacterial distribution and bacterial activity in the sediment}

Bacterial densities determined by microscopic direct counts varied between 0.8 and $52.3 \times 10^{8}$ cells $\mathrm{ml}^{-1}$ (Table 3). The highest bacterial counts were frequently in the topmost layer or in the immediately subjacent sediment layer Bacterial densities decreased rapidly with burial, with bacterial counts dropping to $10 \%$ of their maximal value at $11 \mathrm{~cm}$ depth (Table 3).

Measured rates for proteolytic activity are shown in Table 4 . The highest rate was never in the topmost layer; at best it was in the 1 to $2 \mathrm{~cm}$ deep layer. In most of the cores studied, the maximal activity appeared in the 5 to $7 \mathrm{~cm}$ layer, where we observed the highest average rate

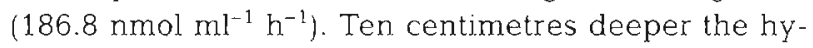
drolysis rate decreased and was less than $10 \%$ of this maximal average rate (Table 4). Mineralization rates of glutamate through the sediment thickness showed a different pattern (Table 5). The highest rates were observed in the upper layers, mostly between the surface and $3 \mathrm{~cm}$ depth, where the average values ranged between 189.5 and $161.0 \mathrm{nmol} \mathrm{C}^{-1} \mathrm{~h}^{-1}$. Below $7 \mathrm{~cm}$ depth mineralization rates decreased drastically to a few percent of their optimal values (Table 5).

Table 2. Bacterial densities, bacterial biomasses and potential rates for ${ }^{14} \mathrm{C}$-glutamate utilization in the near bottom waters. Biomass estimated by using a conversion factor of $20 \times 10^{-15} \mathrm{~g} \mathrm{C}$ cell $^{-1}$ (Lee \& Fuhrman 1987). Uptake = Incorporatıon + Respiration. Respiration $\%=$ Respiration $\times 100 /$ Uptake. Average $=$ mean $\pm S E, n=9$

\begin{tabular}{|c|c|c|c|c|c|c|c|}
\hline Station & $\begin{array}{l}\text { Depth } \\
\text { (m) }\end{array}$ & $\begin{array}{c}\text { Bacteria } \\
\left(\times 10^{4} \mathrm{ml}^{-1}\right)\end{array}$ & $\begin{array}{l}\text { Biomass } \\
\left\{\mu \mathrm{C} \mathrm{Cl}^{-1}\right\}\end{array}$ & 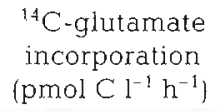 & $\begin{array}{l}{ }^{i 4} \mathrm{C} \text {-glutamate } \\
\text { respiration } \\
\text { (pmol } \mathrm{Cl}^{-1} \mathrm{~h}^{-1} \text { ) }\end{array}$ & $\begin{array}{l}\text { Uptake } \\
\text { (pmol C } \\
\mathrm{l}^{-1} \mathrm{~h}^{-1} \text { ) }\end{array}$ & $\begin{array}{c}\text { Respiration } \\
(\%)\end{array}$ \\
\hline KTB 01 & 1150 & 6.0 & 1.20 & 15.8 & 29.0 & 44.8 & 64.7 \\
\hline KTB 09 & 620 & 5.5 & 1.10 & 16.2 & 42.0 & 58.2 & 72.2 \\
\hline KTB 15 & 1175 & 8.2 & 1.64 & 25.8 & 18.9 & 44.7 & 42.3 \\
\hline KTB 20 & 775 & 5.9 & 1.18 & 4.7 & 19.4 & 24.1 & 80.5 \\
\hline KTB 26 & 1230 & 6.6 & 1.32 & 9.0 & 16.1 & 25.1 & 64.1 \\
\hline КТВ 29 & 585 & 7.6 & 1.52 & 5.2 & 9.3 & 14.5 & 64.1 \\
\hline КТВ 33 & 2065 & 12.0 & 2.40 & 4.9 & 8.3 & 13.2 & 62.9 \\
\hline KTB 38 & 1050 & 29.2 & 5.84 & 11.2 & 39.5 & 50.7 & 77.9 \\
\hline KTB 43 & 1310 & 6.9 & 1.38 & 17.5 & 23.5 & 41.0 & 57.3 \\
\hline Average & & $9.76 \pm 2.51$ & $1.95 \pm 050$ & $12.25 \pm 2.39$ & $22.88 \pm 3.99$ & $35.14 \pm 5.43$ & $65.1 \pm 3.8$ \\
\hline
\end{tabular}




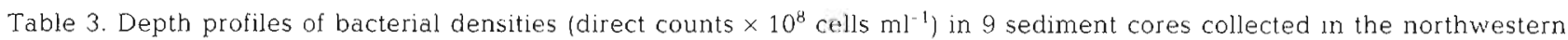
Mediterranean Sea. For each core maximal values are underlined

\begin{tabular}{|c|c|c|c|c|c|c|c|c|c|c|c|}
\hline Station & $\begin{array}{c}\text { Depth } \\
(\mathrm{m})\end{array}$ & $\begin{array}{c}0-0.5 \\
\mathrm{~cm}\end{array}$ & $\begin{array}{c}0.5-1 \\
\mathrm{~cm}\end{array}$ & $\begin{array}{l}1-2 \\
\mathrm{~cm}\end{array}$ & $\begin{array}{l}2-3 \\
\mathrm{~cm}\end{array}$ & $\begin{array}{l}3-5 \\
\mathrm{~cm}\end{array}$ & $\begin{array}{l}5-7 \\
\mathrm{~cm}\end{array}$ & $\begin{array}{c}11-12 \\
\mathrm{~cm}\end{array}$ & $\begin{array}{c}17-20 \\
\mathrm{~cm}\end{array}$ & $\begin{array}{c}40-41 \\
\mathrm{~cm}\end{array}$ & $\begin{array}{l}0-7 \\
\mathrm{~cm}^{\circ}\end{array}$ \\
\hline КТВ 01 & 1150 & 43.5 & $\underline{4} 3.9$ & 28.2 & 15.0 & 17.1 & 5.2 & & & & 131.5 \\
\hline КТВ 09 & 620 & 19.3 & 19.7 & 32.0 & 15.6 & 18.8 & 7.7 & & 5.0 & & 120.1 \\
\hline KTB 15 & 1175 & 11.4 & 8.3 & 7.7 & 11.2 & 16.6 & 10.0 & & 2.9 & 4.4 & 81.9 \\
\hline KTB 20 & 775 & $\underline{28.9}$ & 11.7 & 10.9 & 8.8 & 6.4 & 11.9 & & 5.0 & & 76.6 \\
\hline KTB 26 & 1230 & $\overline{26.4}$ & 49.7 & 32.6 & 9.2 & 4.0 & 8.2 & & 2.3 & & 104.2 \\
\hline KTB 29 & 585 & 38.3 & 25.7 & 35.7 & 31.0 & 32.0 & 19.7 & 2.5 & 1.5 & & 202.1 \\
\hline KTB 33 & 2065 & 10.6 & 15.4 & 15.3 & 5.0 & 9.4 & 2.3 & 2.2 & 1.4 & & 56.7 \\
\hline КТВ 38 & 1050 & $\underline{52.3}$ & 12.5 & 16.2 & 10.8 & 3.2 & 2.3 & 2.6 & 0.9 & 0.8 & 70.4 \\
\hline KTB 43 & 1310 & 24.5 & 9.6 & $\underline{28.0}$ & 9.8 & 3.8 & 12.9 & 3.8 & 2.1 & & 80.8 \\
\hline Average & & 28.4 & 21.9 & 24.2 & 12.4 & 12.4 & 8.3 & 2.8 & 2.4 & 2.6 & 102.7 \\
\hline
\end{tabular}

Table 4. Vertical profiles of potential proteolytic activities ( $\mu$ mol $\mathrm{MCA} \mathrm{l}^{-1} \mathrm{~h}^{-1}$ ) in 9 sediment cores collected in the northwestern Mediterranean Sea. For each core maximal values are underlined. nd: not detectable

\begin{tabular}{|c|c|c|c|c|c|c|c|c|c|c|c|}
\hline Station & $\begin{array}{l}\text { Depth } \\
(\mathrm{m})\end{array}$ & $\begin{array}{c}0-0.5 \\
\mathrm{~cm}\end{array}$ & $\begin{array}{c}0.5-1 \\
\mathrm{~cm}\end{array}$ & $\begin{array}{l}1-2 \\
\mathrm{~cm}\end{array}$ & $\begin{array}{c}2-3 \\
\mathrm{~cm}\end{array}$ & $\begin{array}{l}3-5 \\
\mathrm{~cm}\end{array}$ & $\begin{array}{l}5-7 \\
\mathrm{~cm}\end{array}$ & $\begin{array}{c}11-12 \\
\mathrm{~cm}\end{array}$ & $\begin{array}{c}17-20 \\
\mathrm{~cm}\end{array}$ & $\begin{array}{c}40-41 \\
\mathrm{~cm}\end{array}$ & $\begin{array}{l}0-7 \\
\mathrm{~cm}^{\mathrm{d}}\end{array}$ \\
\hline KTB 01 & 1150 & 25.2 & 18.0 & 51.6 & 54.4 & 88.8 & 108.0 & & & & 521.2 \\
\hline KTB 09 & 620 & 48.0 & 46.8 & 148.4 & 102.0 & 106.8 & 80.0 & & & & 671.4 \\
\hline KTB 15 & 1175 & 118.4 & 92.4 & 132.8 & 155.2 & 164.4 & 150.4 & & 1.6 & 0.8 & 1023.0 \\
\hline $\bar{K} T \mathrm{~B} 20$ & 775 & $126 \hat{6} 4$ & 133.2 & 202.0 & 170.8 & 172.0 & 233.2 & & 2.8 & & 1325.0 \\
\hline KTB 26 & 1230 & 256.8 & 487.2 & 576.0 & 460.8 & 492.8 & 464.0 & 296.0 & 56.8 & & 3322.4 \\
\hline КТВ 29 & 585 & 80.4 & 79.2 & 170.8 & 149.6 & 162.4 & 140.4 & 28.0 & 0.8 & & 1005.8 \\
\hline KTB 33 & 2065 & 22.0 & 86.4 & 119.6 & 63.6 & 69.6 & 222.4 & 98.4 & 58.0 & & 821.4 \\
\hline KTB 38 & 1050 & 82.4 & 148.8 & 106.0 & 118.4 & 124.4 & 164.8 & 29.6 & 1.6 & nd & 918.4 \\
\hline KTB 43 & 1310 & 64.0 & 115.6 & 128.4 & 1988 & 116.0 & 116.0 & 26.8 & 2.8 & & 881.0 \\
\hline Average & & 91.6 & 134.0 & 181.6 & 163.6 & 166.4 & 186.8 & 95.6 & 17.6 & & 1165.5 \\
\hline
\end{tabular}

Table 5. Vertical profiles of ${ }^{14} \mathrm{C}$-glutamate potential remineralization rates (pmol $\mathrm{C} \mathrm{ml}^{-1} \mathrm{~h}^{-1}$ ) in 9 sediment cores collected in the northwestern Mediterranean Sea. For each core maximal values are underlined. nd: not detectable

\begin{tabular}{|c|c|c|c|c|c|c|c|c|c|c|c|}
\hline Station & $\begin{array}{l}\text { Depth } \\
\text { (m) }\end{array}$ & $\begin{array}{c}0-0.5 \\
\mathrm{~cm}\end{array}$ & $\begin{array}{c}0.5-1 \\
\mathrm{~cm}\end{array}$ & $\begin{array}{l}1-2 \\
\mathrm{~cm}\end{array}$ & $\begin{array}{l}2-3 \\
\mathrm{~cm}\end{array}$ & $\begin{array}{l}3-5 \\
\mathrm{~cm}\end{array}$ & $\begin{array}{l}5-7 \\
\mathrm{~cm}\end{array}$ & $\begin{array}{c}11-12 \\
\mathrm{~cm}\end{array}$ & $\begin{array}{c}17-20 \\
\mathrm{~cm}\end{array}$ & $\begin{array}{c}40-41 \\
\mathrm{~cm}\end{array}$ & $\begin{array}{r}0 \text { to } 7 \\
\mathrm{~cm}^{r}\end{array}$ \\
\hline KTB 01 & 1150 & 125.9 & 80.8 & 129.4 & 96.6 & 65.8 & 15.5 & & & & 0.49 \\
\hline КТВ 09 & 620 & 270.9 & 133.4 & 89.8 & 177.7 & 162.9 & 122.7 & & 0.1 & & 1.04 \\
\hline KTB 15 & 1175 & 163.5 & 155.8 & 221.5 & 207.4 & 228.5 & $\underline{276.2}$ & & 6.7 & nd & 1.60 \\
\hline КТВ 20 & 775 & 180.7 & 189.7 & 164.0 & 200.7 & 75.5 & 11.5 & & 1.6 & & 0.72 \\
\hline KТВ 26 & 1230 & 88.6 & 48.1 & 50.0 & 65.2 & 36.6 & 33.4 & & 1.4 & & 0.32 \\
\hline KTB 29 & 585 & 241.3 & 330.3 & 337.4 & 268.6 & 252.1 & 111.1 & 5.5 & 0.8 & & 1.62 \\
\hline KTB 33 & 2065 & 82.8 & 118.3 & 127.6 & 36.6 & 41.7 & 34.3 & 5.5 & 1.9 & & 0.42 \\
\hline KTB 38 & 1050 & $\underline{361.2}$ & 124.2 & 255.4 & 252.6 & 77.5 & 46.3 & 5.3 & 18.4 & nd & 1.00 \\
\hline KTB 43 & 1310 & 190.8 & 288.7 & 130.8 & 143.9 & 60.9 & 14.9 & 1.6 & & & 0.68 \\
\hline average & & 189.5 & 163.3 & 167.3 & 161.0 & 111.3 & 74.0 & 4.5 & 4.4 & & 0.88 \\
\hline
\end{tabular}




\section{DISCUSSION}

\section{Significance of bacterial activity measurements in sediment samples}

Practitioners of the radiotracer technique are aware of the difficulties in clearly defining the actual significance of metabolic rates measured when applying this technique to aquatic samples. These difficulties are due to the multiphasic uptake of organic substrates by monospecific cultures (Nissen et al. 1984), worsened by the specific diversity of natural bacterial consortia gathering species with different kinetic parameters (Krambeck 1979). When working with sediment samples, experimental difficulties further complicated both by the poor diffusion of the introduced radiolabeled compound within a solid sample (Meyer-Reil 1986) and by the compound's rapid adsorption onto the particles (Drogue et al. 1985). For these reasons every experimental strategy is subject to justified criticisms. Our data are based on measurements made during time course experiments for a $6 \mathrm{~h}$ incubation period using sediment slurries enriched with $1 \mu \mathrm{M}{ }^{14} \mathrm{C}$-glutamate, while the natural concentration of glutamate in the superficial layer of sediment in these margins is nearly $0.15 \mu \mathrm{M}$ (R. Buscail unpubl.). Unfortunately it is impossible to determine the actual availability of glutamate for benthic bacteria due to its adsorption onto the particles (Keil et al. 1994).

Another experimental problem is the difficulty of keeping sediment samples under natural pressure conditions. Our results are based on microbial activity measurements conducted on samples decompressed during retrieval. Presently, the effects of this physiological stress on the metabolic activity measurements for benthic bacteria are unclear. Results from experiments done in situ at the deep water sediment interface are contradictory: Jannasch \& Wirsen (1973) observed that the in situ microbial response to enrichment of deep sea water and sediment was 1 to 3 orders of magnitude lower than in the controls incubated under atmospheric pressure conditions, in contrast to Cahet et al. (1990) and Buscail \& Guidi-Guilvard (1993), who measured higher metabolic rates for benthic bacteria during in situ incubation than in their decompressed counterparts. Results of experiments done on sediment samples recompressed on board the research vessel are also contradictory: Meyer-Reil \& Köster (1992) did not observe a pronounced stimulation of enzyme activity by in situ pressure conditions, in contrast to Deming \& Colwell (1985), Lochte \& Turley (1988), Turley \& Lochte (1990) and Poremba (1994), who all observed degradation rates stimulated by recompression. These observations suggest that sinking particles and phytodetritus reaching abyssal depths are recolonized by barophilic bacteria. In consequence, the measured rates must be considered to be potential rates, as we cannot define what the actual metabolic rates under the natural pressure conditions should be.

\section{Near bottom water: endpoint of the water column}

The overall mean value for bacterial densities in the NBW is $9.76 \pm 2.5 \times 10^{4}$ cells $\mathrm{ml}^{-1}(\mathrm{n}=9)$ for an average depth of $1106 \mathrm{~m}$. This is 1.5 -fold the average density $\left(6.3 \pm 0.7 \times 10^{4}\right.$ cells $\left.\mathrm{ml}^{-1}\right)$ observed during the same cruise by Turley et al. (1996) on 6 samples of intermediate water (IW) collected at an average depth of $831 \mathrm{~m}$, and twice the average bacterial density $\left(4.8 \pm 0.9 \times 10^{4}\right.$ cells $\mathrm{ml}^{-1}$ ) we previously observed in a set of 16 samples of water collected at an average depth of $1363 \mathrm{~m}$ in the northwestern Mediterranean (data not shown).

Mean value for glutamate uptake rates in the near bottom water $\left(35.14 \pm 5.43 \mathrm{pmol} \mathrm{Cl}^{-1} \mathrm{~h}^{-1}\right)$ were almost 7 -fold higher than the rates $(4.95 \pm 1.44, \mathrm{n}=5)$ observed during the same cruise by Iriberri et al. (1996) in the corresponding IW collected at an average depth of $822 \mathrm{~m}$. This pattern could be due to an enrichment of the NBW with labile low molecular organic compounds exuded, or egested, by the benthic metazoans, or produced by enhanced bacterial hydrolytic activity. However, no correlation was found between bacterial density and total organic carbon bulk in the NBW (Table 6).

From these data the mean specific activity per cell was $3.6 \times 10^{-4} \mathrm{fmol} \mathrm{C}$ cell ${ }^{-1} \mathrm{~h}^{-1}$ in the NBW, and $0.78 \times$ $10^{-4} \mathrm{fmol} \mathrm{C}$ cell $^{-1} \mathrm{~h}^{-1}$ in the IW (as calculated from Iriberri et al. 1996 and Turley et al. 1996). Although the actual significance of per-cell activity remains unclear (Novitsky 1983, Ritzrau et al. 1997), the enhancement of remineralization processes in the NBW seems to be predominantly provoked by an increase in the specific activity per cell (4.6-fold increase) more than by an increase in bacterial densities (1.6-fold increase). Indeed, one could expect that the permanent input of bacteria from sinking particles at the end point of the water column (estimated to be $1.1 \times 10^{12}$ cells $\mathrm{m}^{-2} \mathrm{yr}^{-1}$ at $3100 \mathrm{~m}$ depth in the NE Atlantic; Turley \& Mackie 1995), strengthened by the observed boost of bacterial activities, should lead to a more significant rise in bacterial densities. This pattern suggested that both these processes could be counterbalanced by a concomitant enhancement of grazing efficiency in the NBW.

\section{Bathymetry, topography, and current incidence on benthic microbial populations}

Bacterial abundance and rate of metabolic activity in the NBW and in the topmost sediment layer were not 
Table 6. Correlation-matrix (non-parametric test, Spearman correlation coefficient, $\mathrm{n}=9$ ) between biological parametcrs (BA: bacterial abundance, PRR: potential respiration rate, PEA: potential ectoproteolytic activity), a chemical parameter (TOC: total organic carbon) and depth in near bottom water (NBW) and a $0-0.5 \mathrm{~cm}$ thick superficial layer of sediment (SSED). (TOC data from R. Buscail unpubl.)

\begin{tabular}{|c|c|c|c|c|c|c|c|c|}
\hline & $\begin{array}{l}\text { NBW } \\
\text { BA }\end{array}$ & $\begin{array}{l}\text { NBW } \\
\text { PRR }\end{array}$ & $\begin{array}{l}\text { NBW } \\
\text { TOC }\end{array}$ & $\begin{array}{c}\text { SSED } \\
\text { BA }\end{array}$ & $\begin{array}{l}\text { SSED } \\
\text { PRR }\end{array}$ & $\begin{array}{l}\text { SSED } \\
\text { PEA }\end{array}$ & $\begin{array}{l}\text { SSED } \\
\text { TOC }\end{array}$ & DEPTH \\
\hline $\begin{array}{l}\text { NBW } \\
\mathrm{BA}\end{array}$ & 1 & & & & & & & \\
\hline $\begin{array}{l}\text { NBW } \\
\text { PRR }\end{array}$ & $\begin{array}{c}-0.38 \\
(p=0.278)\end{array}$ & 1 & & & & & & \\
\hline $\begin{array}{l}\text { NBW } \\
\text { TOC }\end{array}$ & $\begin{array}{c}-0.38 \\
(p=0.354)\end{array}$ & $\begin{array}{c}0.31 \\
(p=0.444)\end{array}$ & 1 & & & & & \\
\hline $\begin{array}{l}\text { SSED } \\
\text { BA }\end{array}$ & $\begin{array}{c}-0.02 \\
(p=0.962)\end{array}$ & $\begin{array}{c}0.37 \\
(p=0.299)\end{array}$ & $\begin{array}{c}-0.81 \\
(p=0.047)\end{array}$ & 1 & & & & \\
\hline $\begin{array}{l}\text { SSED } \\
\text { PRR }\end{array}$ & $\begin{array}{c}-0.02 \\
(p=0.962)\end{array}$ & $\begin{array}{c}0.63 \\
(p=0.07)\end{array}$ & $\begin{array}{c}-0.2 \\
(\mathrm{p}=0.627)\end{array}$ & $\begin{array}{c}0.43 \\
(p=0.22)\end{array}$ & 1 & & & \\
\hline $\begin{array}{l}\text { SSED } \\
\text { PEA. }\end{array}$ & $\begin{array}{c}-0.05 \\
(\mathrm{p}=0.887)\end{array}$ & $\begin{array}{c}-0.1 \\
(p=0.777)\end{array}$ & $\begin{array}{c}0.14 \\
(p=0.724)\end{array}$ & $\begin{array}{c}0.22 \\
(p=0.54)\end{array}$ & $\begin{array}{c}0.08 \\
(p=0.814)\end{array}$ & 1 & & \\
\hline $\begin{array}{l}\text { SSED } \\
\text { TOC }\end{array}$ & $\begin{array}{c}0.43 \\
(p=0.22)\end{array}$ & $\begin{array}{c}0.07 \\
(p=0.85)\end{array}$ & $\begin{array}{c}-0.11 \\
(p=0.791)\end{array}$ & $\begin{array}{c}0.2 \\
(\mathrm{p}=0.571)\end{array}$ & $\begin{array}{c}-0.13 \\
(p=0.706)\end{array}$ & $\begin{array}{c}0.23 \\
(p=0.509)\end{array}$ & 1 & \\
\hline DEPTH & $\begin{array}{c}0.37) \\
(p=0.299)\end{array}$ & $\begin{array}{c}-0.35 \\
(\mathrm{p}=0.322)\end{array}$ & $\begin{array}{c}0.29 \\
(p=0.48)\end{array}$ & $\begin{array}{c}-0.5 \\
(p=0.157)\end{array}$ & $\begin{array}{c}-0.68 \\
(p=0.053)\end{array}$ & $\begin{array}{c}-0.17 \\
(p=0.637)\end{array}$ & $\begin{array}{c}0.15 \\
(p=0.672)\end{array}$ & 1 \\
\hline
\end{tabular}

correlated with the sampling depth (Table 6). This is a general trend observed by Deming \& Baross (1993), Danovaro et al. (1993) and Boetius et al. (1996). This lack of corrclation could be due to the diversity and variability of parameters linked to the variation of depth, particularly in continental margin areas. An increase in depth does not necessarily mean an increase in sedimentation time and an increase in distance from the coast (i.e. lowering the availability of readily utilizable low molecular weight organic compounds). Maximal bacterial densities and uptake rates appeared in the water collected from the bottom of the canyon as well as from the open slope area (Table 2), showing a poor influence of bottom topography on bacterial distribution and metabolic rates in the NBW. However, in the deposited sediments $(0-0.5 \mathrm{~cm}$ topmost layer), bacterial densities (Table 3) and metabolic rates (Tables $4 \& 5$ ) appeared generally higher in the samples collected from the open slope than in those collected in the axial channel of the canyon, where Buscail \& Germain (1997) observed a preferential organic carbon accumulation. These authors attributed the low organic carbon content along the open slope to the long residence time at the sediment water interface, which allows for substantial early diagenesis. Our data confirmed the enhancement of hydrolysis and mineralization rates in the topmost sediment layer of the open slope versus the axis channel of the canyon.

The major differences appeared when comparing the different sampling zones. Indeed, the highest values for bacterial respiration rates in the NBW were recorded in the Planier and Foix canyons, which are characterized by the highest fluxes of particulate organic carbon (Heussner et al. 1996). Conversely, the lowest flows were measured in the Balearic zone, which is the most oligotrophic of the northwestern Mediterranean (P. Conan unpubl.). The highest bacterial count $\left(202.1 \times 10^{8}\right.$ cells $\left.\mathrm{cm}^{-2}\right)$ and the highest flow of mineralization (1.62 $\mathrm{nmol} \mathrm{C} \mathrm{cm}^{-2} \mathrm{~h}^{-1}$ ) recorded in the KTB 29 core collected at $585 \mathrm{~m}$ depth in the Balearic zone confirm the difficulty of defining general trends in bacterial activity regulation in a continental margin area. The local hydrological regime strongly interacts with bottom topography in determining the sedimentation pattern. The North Mediterranean Current, located along the continental slope (Fig. 1), can interact with the coastal inputs, particularly in the Gulf of Lions and on the Catalan margin.

\section{Benthic versus pelagic bacterial biomass and remineralization potential}

It is obvious that bacterial counts and remineralization rates are clearly higher in the superficial layer of sediment than in the immediate overlying water. Average bacterial abundance and mineralization rates for the topmost $5 \mathrm{~mm}$. thick sediment layer were 4 orders of magnitude higher than those found in the overlying water. Such a large difference seems to be common (Novitsky 1983, Talbot \& Bianchi 1997). Furthermore, bacterial counts in the topmost sediment layer did not 
correlate with counts from the corresponding NBW (Table 6). These observations could suggest a clear differentiation of microbial populations right through the benthic boundary layer, and could argue for the predominance of sedimentary over aquatic bacterial remineralization activity. Indeed, a comparison of average counts and rates cannot be considered as representative of the flow processed by bacterial communities through the pelagic or benthic systems. As Turley et al. (1996) and Iriberri et al. (1996) measured the bacterial densities and mineralization rates in several samples collected through the water column at 3 sampling stations (Planier, Lacaze-Duthiers and Balearic Islands Zones) during the same cruise, we had the possibility of extending the comparison over the whole water column (WWC).

From our data, the integrated bacterial population in the 0 to $7 \mathrm{~cm}$ sediment layer was estimated to be $1.02 \times$ $10^{14}$ bacteria $\mathrm{m}^{-2}$. If we compare this value to those calculated from bacterial counts obtained by Turley et al. (1996) in the WWC $\left(1.62 \times 10^{14}\right.$ bacteria $\left.\mathrm{m}^{-2}\right)$, it appears that $61 \%$ of the total bacterial cells are dispersed in the $\sim 800 \mathrm{~m}$ deep water column, while $39 \%$ are concentrated in the 0 to $7 \mathrm{~cm}$ deep layer of sediment. Similarly, the remineralization flows through this $7 \mathrm{~cm}$ thick sediment layer and over the entire extent of the water column (calculated from Iriberri et al. 1996) were determined to be 8.80 and $18.53 \mu \mathrm{mol} \mathrm{CO}_{2} \mathrm{~m}^{-2} \mathrm{~h}^{-1}$, respectively. Thus, it appears that $68 \%$ of the carbon dioxide theoretically produced by bacterial respiration throughout the same oceanic area would be due to the activity of pelagic bacteria, whereas the corresponding benthic bacteria would contribute only $32 \%$ to the potential mineralization flow. One could argue that the low rates we observed in the sediment samples are due to the adsorption of the radiolabeled tracer to the clay minerals (Drogue et al. 1985), or to their condensation with natural organic compounds, leading to the formation of non-labile geopolymers (Buscail \& Gadel 1991). Indeed, these processes likely reflect the low availability of natural and labeled organic compounds to bacteria due to their adsorption on sediment particles (Keil et al. 1994). This leads us to allocate a smaller role to benthic bacteria than to pelagic bacteria in the remineralization flow through the global oceanic system.

\section{Evolution of microbial activities during the first stages of burial}

The maximal bacterial densities were usualiy in the $1 \mathrm{~cm}$ thick surface layer. As this superficial layer is frequently fuelled by settling organic particles, and because $-90 \%$ of the grazers are concentrated in this layer (De Bovée et al. 1990), one could hypothesize that bac- terial densities are likely limited more by top-down control than by nutrient limitation. A clear decrease in bacterial densities appeared below $2 \mathrm{~cm}$ depth (Table 3 ). Below the layer enriched by sediment reworking, grazers are less numerous. Therefore, in the immediate subsurface sediments, bacterial abundance may well be limited by bottom-up control due to nutrient exhaustion.

The average glutamate mineralization rate was homogeneous in the 4 sediment slices we studied throughout the $3 \mathrm{~cm}$ thick upper layer (Table 5). This activity decreased drastically below $7 \mathrm{~cm}$ depth. In contrast, and surprisingly because the boundary layer is permanently fuelled by polymer-rich particles sinking down from the productive areas of the water column, hydrolysis rates appeared minimal in the topmost sediment layer (Table 4). Proteolysis rate increased progressively with increasing depth. This activity appeared maximal between a depth of 5 and $7 \mathrm{~cm}$, being significantly different from the topmost layer ( $t$ test, $\mathrm{p} \leq 0.05$ ). At this depth microbial abundance and mineralization rates were already nearly one-third of their maximal values in the superficial layer The drastic decrease in proteolytic activity rates appeared only at a depth of between 12 and $17 \mathrm{~cm}$ (Table 4), that is, below the redox discontinuity layer $(R$. Buscail unpubl.), where massive inputs from the sediment surface by reworking processes become more unlikely (Sanchez-Cabeza 1996).

The pattern we observed for proteolytic activities in these Mediterranean sediments is in contrast to the decreasing gradient usually described (King 1986, Meyer-Reil 1987, Mayer 1989, Talbot \& Bianchi 1997). However, irregular profiles showing a peak of activity just below the surface were also occasionally observed in some of the cores collected in the NE Atlantic by Poremba (1995), in the Celtic Sea (Poremba \& Hoppe 1995) or in the Eastern Mediterranean (Boetius et al. 1996). Such a pattern could suggest 2 hypotheses: (1) an enhancement of hydrolytic activities in the subsurface sediment or (2) an inhibitory effect on these activities in the topmost layer.

The former hypothesis could be supported by an increase if the concentration of protein-like compounds in the 2 to $7 \mathrm{~cm}$ deep layer Boetius \& Lochte (1994) suggested such an hypothesis, pointing out that dissolved macromolecular compounds have a good chance of diffusing through the sediment. These subsurface polymers may be associated with biogenic structures, i.e. excreted for strengthening burrow walls, faecal pellets or dead bodies of benthic fauna (Köster et al. 1991, Mayer 1993). This enrichment could provoke the selective growth of protease-producing bacteria, and the observed peak in proteolysis rate.

The latter hypothesis could be supported by the gradient of readily utilizable dissolved organic matter 
(RUDOM) usually observed in the sediment thickness Danovaro et al. (1993) and R. Buscail (unpubl.) described a decline of labile organic matter through the sediment thickness. The high bacterial densities and respiration rates we observed in the superficial layer of the sediment confirm the availability of RUDOM in the topmost layer. Availability of RUDOM compounds may inhibit the production and activity of ectoenzymes, as observed by Chrost (1991) for the regulation of hydrolytic activities during phytoplankton blooms, and by Boetius \& Lochte $(1994,1996)$ during experimental inputs of organic particles or polymers to deep sea sediment slurries. In the superficial layer of the sediment the organic bulk provides the monomers that bacteria need to be physiologically active. In these conditions the hydrolysis of polymers is not a basic survival process, as shown by the lack of correlation between respiration and proteolysis rates (Table 6).

Further evidence supporting this hypothesis is offered by the study of a core from Stn KTB 26, collected at $1230 \mathrm{~m}$ depth in the Balearic Islands Canyon. This core shows an exceptionally low glutamate mineralization activity resulting in an integrated rate of 0.32 $\mathrm{nmol} \mathrm{C} \mathrm{cm}{ }^{-2} \mathrm{~h}^{-1}$ although the average rate is $0.88 \mathrm{nmol}$ $\mathrm{C} \mathrm{cm}^{-2} \mathrm{~h}^{-1} \pm 0.20$ ( $\mathrm{n}=9$ ) (Table 5). Conversely, this core exhibited the highest proteolytic activity $(3322 \mathrm{nmol}$ MCA cm ${ }^{-2} \mathrm{~h}^{-1}$ ), 3-fold higher than the mean integrated flux (1165 nmol MCA cm ${ }^{-2} \mathrm{~h}^{-1} \pm 279.9, \mathrm{n}=9$; Table 4). In this area the organic carbon flux to the bottom is the lowest among the sites studied (Heussner et al. 1996); as a consequence, RUDOM is probably exhausted before reaching the seafloor. Therefore, to be active, benthic bacteria must be adapted to the hydrolysis of organic polymers. This strategy works because, despite the scarcity of organic inputs, the microbial population is not lower than average (Table 3). This pattern confirms the hypothesis that efficiency of the organic polymer hydrolysis is optimal only when RUDOM is exhausted.

During the early stages of burial living bacteria have an effect on the potential redox conditions. At most of the sites the transition zone between oxidized and reduced layers appeared between 4 and $6 \mathrm{~cm}$ (R. Buscail unpubl.), that is, immediately above the level at which there was a severe decrease in bacterial densities (Table 3) and respiration rates (Table 5). The highest positive potential redox values (>300 $\mathrm{mV}$ ) were in the Balearic Islands zone, where negative values appeared only at a depth of between 12 and $18 \mathrm{~cm}$. In this area, the microphytoplankton productivity and the organic $C$ flux from the water column were the poorest among the 4 zones we visited during this cruise (Heussner et al. 1996). Furthermore, the Balearic Islands sediments are fine carbonate clays, from which it is difficult for bacteria to extract organic matter. Con- sequently, bacterial densities and bacterial respiration rates were lower than at the other sites, leading to deeply oxidized sediments, except for KTB 29. Despite having the highest $(57 \%)$ carbonate concentration found in this study, these sediments support the highest bacterial density $\left(201.6 \times 10^{8}\right.$ cells $\left.\mathrm{cm}^{-2}\right)$ and the highest respiration flow $\left(1.62 \mathrm{nmol} \mathrm{C} \mathrm{cm}^{-2} \mathrm{~h}^{-1}\right)$. Indeed this core is the shallowest ( $585 \mathrm{~m}$ deep) we studied, an observation which shows how difficult it is to describe universal trends in benthic microbiology.

In these margin sediments the integrated bacterial population throughout the 0 to $2 \mathrm{~cm}$ layer was $49.35 \times$ $10^{8}$ bacteria $\mathrm{cm}^{-2}$, corresponding to an average bacterial biomass of $\sim 0.1 \mathrm{mg} \mathrm{C} \mathrm{cm}^{-2}$ (i.e. $\sim 90 \mu \mathrm{g}$ bacterial $\mathrm{C}$ $g^{-1}$ dry weight). This average value corresponds to $-1.5 \%$ of the total organic carbon (TOC) bulk. As observed by Danovaro et al. (1993) and Boetius et al. (1996) in other deep Mediterranean samples, the bacterial biomass did not correlate with the organic carbon bulk (Table 6). At $20 \mathrm{~cm}$ depth, i.e. -100 to $200 \mathrm{yr}$ after deposition (Sanchez-Cabeza et al. 1996), the bacterial biomass is nearly one order of magnitude lower than in the topmost layer. Even if the living part of this biomass is renewed at an undetermined rate, such a low percentage in the earliest stages of burial can be considered as confirmation of the minor contribution that bacterial biomass makes to sedimentary organic carbon (Hartgers et al. 1994).

\section{CONCLUSIONS}

The absence of correlation between microbial characteristics and ecological parameters makes it difficult to compare bacterial activities in the different margin areas we studied. Meyer-Reil (1987) already noted that in the Baltic Sea the sediments were characterized by distinct patterns of interrelationships between the individual parameters of microbial activities. Our observations confirm the difficulty of determining what the key parameters for the regulation of the distribution and activity of benthic bacterial populations are.

The superficial layers of sediments are usually characterized by the highest bacterial counts and the highest organic bulk observed over the whole oceanic system. Consistently, values for mineralization rates are also maximal in this surficial layer. These high counts and high rates do not reflect the respective roles of pelagic and benthic bacterial populations. Indeed, the carbon dioxide flow produced by bacteria in the whole water column substantially exceeds the flow produced by bacteria throughout the sediment thickness. Nevertheless, the role of benthic bacteria in the remineralization processes is far from negligible. In the upper mixed layer of sediment, microbial populations appear 
able to remineralize the readily utilizable low molecular weight organic compounds. Immediately below, in the subsurface layers, bacterial populations appear to be well equipped to decompose the high molecular weight organic compounds. This pattern prevents the benthic polymers from being definitively buried in the sediment in the same manner as mesopelagic ocean enzymatic hydrolysis prevents particulate organic matter from sinking to 'depths of no return' (Hoppe et al. 1993). Thus, benthic microbial populations appear to play an important role in early diagenesis processes and a link between pelagic and benthic systems.

Acknowledgements. This research has been undertaken within the framework of the Mediterranean Targeted Project (MTP): European Microbiology of Particulate Systems (EMPS) and EUROMARGE-NB projects. We acknowledge the support from the European Commission's Marine Science and Technology (MAST) Programme under contracts MAS2CT94-0090 and MAS90053. We thank C. Turley and J. Iriberri for providing microbiological data from the water column, and R. Buscail for the data set of chemical analysis. The authors are grateful to Carol Turley, Rocelyne Rusrail Richard Sempéré, France van Wambeke, Micheline Bianchi, Christophe Rabouille, and 3 anonymous reviewers for helpful comments on the manuscript. Special thanks to the captain and crew of the RV 'Suroit' for cruise assistance.

\section{LITERATURE CITED}

Barnett PRO, Watson J, Connelly D (1984) A multiple corer for taking virtually undisturbed samples from shelf, bathyal and abyssal sediments. Oceanol Acta 7:399-408

Bensoussan M, Bianchi A (1983) Distribution et activité catabolique potentielle des communautés bactériennes des eaux et des sédiments profonds prélevés sur diverses marges continentales. In: Combaz A (ed) Géochimie organique des sédiments marins d'Orgon à Misedor. Editions du CNRS, Paris, p 39-72

Boetius A, Lochte K (1994) Regulation of microbial enzymatic degradation of organic matter in deep-sea sediments. Mar Ecol Prog Ser 104:299-307

Boetius A, Lochte K (1996) Effect of organic enrichments on hydrolytic potentials and growth of bacteria in deep-sea sediments. Mar Ecol Prog Ser 140:239-250

Boetius A, Scheibe S, Tselipides A, Thiel H (1996) Microbial bromass and activities in deep-sea sediments of the Eastern Mediterranean: trenches are benthic hotspots. Deep Sea Res I, 43:1439-1460

Buscail R, Ambatsian P, Monaco A, Bernat M (1997) ${ }^{210} \mathrm{~Pb}$, manganese and carbon: indicators of focusing processes on the northwestern Mediterranean continental margin. Mar Geol 137:271-286

Buscail R, Gadel F (1991) Transfer and biogeochemistry of organic matter at sediment-water interface on the northwestern Mediterranean margin. In: Berthelin J (ed) Diversity of environmental biogeochemistry, Vol 13. Elsevier Science Publishers, Amsterdam, p 113-130

Buscail R, Germain C (1997) Present-day organic matter sedimentation on the NW Mediterranean margin: importance of off-shore export. Limnol Oceanogr 42:217-229
Buscail R, Guidi-Guilvard L (1993) Organic inputs and transformations at the sediment-water interface of the NW Mediterranean slope (Gulf of Lions - France). Ann Inst Océanogr 69:147-153

Cahet G, Daumas R, Sibuet M (1990) In situ experimentation at the water/sediment interface in the deep sea: 2 . Biotransformation of dissolved organic substrates by microbial communities at $2000 \mathrm{~m}$ depth in the Bay of Biscay. Prog Oceanogr 24:169-178

Canals M, Euromarge-NB Group (1997) Transfer of matter and energy on European continental margins. In: Lipiatou $E$ (ed) Interdisciplinary research in the Mediterranean Sea. A synthesis of scientific results from the Mediterranean targeted project (MTP) phase I, 1993-1996. Official Publication of the European Communities, Luxembourg, p 33-68

Chrost RJ (1991) Environmental control of the synthesis and activity of aquatic microbial ecloenzymes. In: Chrost RJ (ed) Microbial enzymes in aquatic environments. Springer-Verlag, New York, p 29-59

Danovaro R, Fabiano M, Croce ND (1993) Labile organic matter and microbial biomasses in deep-sea sediments (Eastern Mediterranean Sea). Deep Sea Res 40:953-965

De Bovée FD, Guidi L, Soyer J (1990) Quantitative distribution of deep-sea mejobenthos in the northwestern Mednterranean (Gulf of Lions). Cont Shelf Res 1.0:1123-1145

Deming JW (1985) Bacterial growth in deep-sea sediment trap and boxcore samples. Mar Ecol Prog Ser 25:305-312

Deming JW, Baross JA (1993) The early diagenesis of organic matter; bactenal activity. In: Engel MH, Macko SA (eds) Organic geochemistry. Plenum Press, New York, p 119-144

Deming JW, Colwell RR (1985) Observations of barophilic microbial activity in samples of sediment and intercepted particulates from the Demerara abyssal plain. Appl Environ Microbiol 50:1002-1006

Deming JW, Yager PL (1992) Natural bacterial assemblages in deep-sea sediments: towards a global view. In: Rowe GT, Pariente V (eds) Deep-sea food chains and the global carbon cycle. Kluwer Academic Publishers, Dordrecht, p 11-27

Drogue N, Daumas R, Hermin MN (1985) Adsorption des acides aminés par les sédiments marins et répercussion sur l'activité bactérienne. Rapp PV Comm Int Explor Sci Mer Médit 29:25-26

Hartgers WA, Damsté JSS, Requejo AG, Allan J, Hayes M, Leeuwand JW (1994) Evidence for only minor contributions from bacteria to sedimentary organic carbon. Nature $369: 224-226$

Heussner S, Calafat A, Palanques A (1996) Quantitative and qualitative features of particle fluxes in the North Balearic Basin. In: Canals $M$. Casamor JL, Cacho I, Calafat A, Monaco A (eds) EU ROMARGE-NB Final report, MAST II Programme, EC, Vol 2, p 41-66

Hoppe HG, Ducklow $H$, Karrasch B (1993) Evidence fol dependency of bacterial growth on enzymatic hydrolysis of particulate organic matter in the mesopelagic ocean. Mar Ecol Prog Ser 93:277-283

Iriberri J. Unanue M, Ayo B (1996) Heterotrophic processes associated with the degradation of particulate materal in Mediterranean Sea Waters. In: Bianchi M (ed) European microblology of particulate systems. Final report MAST II Programme, EC, Vol 2, contr no. 4, p 1-41

Jannasch HW, Wirsen CO (1973) Deep-sea microorganisms: in situ response to nutrient enrichment. Science 180 $641-643$

Keil RG, Montluçon DB, PrahI. FG. Hedges JI (1994) Sorptıve preservation of labile organic matter in marine sediments Nature 370:549-551 
King GM (1986) Characterization of beta-glucosidase activity in intertidal marine sediments. Appl Environ Microbiol 51 : $373-380$

Köster M, Jensen P, Meyer-Reil LA (1991) Hydrolytic activities of organisms and biogenic structures in deep-sea sediments. In: Chrost RJ (ed) Microbial enzymes in aquatic environments. Springer-Verlag, New York, p 298-310

Krambeck C (1979) Applicability and limitations of the Michaelis-Menten equation in microbial ecology. Arch Hydrobjol Beih Ergebn Limnol 12:64-76

Lee S, Fuhrman JA (1987) Relationships between biovolume and biomass of naturally derived mane bacterioplankton. Appl Environ Microbiol 53:1298-1303

Lochte K, Turley CM (1988) Bacteria and cyanobacteria associated with phytodetritus in the deep sea. Nature 333 $67-69$

Mayer LM (1989) Extracellular proteolytic enzyme activity in sediments of an intertidal mudflat. Limnol Oceanogr 34 973-981

Mayer LM (1993) Organic matter at the sediment-water interface. In: Engel MH, Macko SA (eds) Organic geochemistry. Plenum Press, New York, p 171-184

Meyer-Reil LA (1986) Measurement of hydrolytic activity and incorporation of dissolved organic substrates by microorganisms in marine sediments. Mar Ecol Prog Ser 31. $143-149$

Meyer-Reil LA (1987) Seasonal and spatial distribution of extracellular enzymatic activities and microbial incorporation of dissolved organic substrates in marine sediments. Appl Environ Microbiol 53:1748-1755

Meyer-Reil LA (1991) Ecological aspects of enzymatic actuvity in marine sedıments. In: Chrost RJ (ed) Microbial enzymes in aquatic environments. Springer Verlag. New York, p $84-95$

Meyer-Reil LA, Köster M (1992) Microbial life in pelagic sediments: the impact of environmental parameters on enzymatic degradation of organic material. Mar Ecol Prog Ser $81: 65-72$

Monaco A, Biscaye $P$, Soyer $J$, Pocklington $R$, Heussner $S$ (1990) Particle fluxes and ecosystem response on a continental margin: the 1985-1988 Mediterranean ECOMARGE experiment. Cont Shelf Res 10:809-839

Nissen H, Nissen P, Azam F (1984) Multiphasic uptake of Dglucose by an oligotrophic marine bacterium. Mar Ecol Prog Ser 16:155-160

Novitsky JA (1983) Heterotrophic activity throughout a vertical profile of seawater and sediment in Halifax harbor, Canada. Appl Environ Microbiol 45:1753-1760

Parkes RJ, Cragg BA, Bale SJ, Getliff JM, Goodman K, Rochelle PA, Frv JC, Weightman AJ, Harvey SM (1994) Deep bacterial biosphere in Pacific Ocean sediments. Nature 371:410-413

Pfannkuche $O$ (1993) Benthic response to the sedimentation of particulate organic matter at the Biotrans station, $47^{\circ} \mathrm{N}$, $20^{\circ} \mathrm{W}$. Deep Sea Res 40:135-149

Editorial responsibility: Otto Kinne (Editor), Oldendorf/Luhe, Germany
Poremba K (1994) Simulated degradation of phytodetritus in deep-sea sediments of the NE Atlantic $\left(47^{\circ} \mathrm{N}, 19^{\circ} \mathrm{W}\right)$. Mar Ecol Prog Ser 105:291-299

Poremba K (1995) Hydrolytic enzymatic activity in deep-sea sediments. FEMS Microbiol Ecol 16:213-222

Poremba K, Eardley D, Patching JW (1994) Dynamics of microbial abundance and activity in deep-sea sediment of the Northeast Atlantic. Microbiol Eur 2:22-25

Poremba K. Hoppe HG (1995) Spatial variation of benthic microbial production and hydrolytic enzymatic activity down the continental slope of the Celtic Sea Mar Ecol Prog Ser 118:237-245

Porter KG, Feig YS (1980) The use of DAPI. for identifying and counting aquatic microflora. Limnol Oceanogr 25:943-948

Ritzrau W, Thomsen L, Lara RJ, Graf G (1997) Enhanced microbial utilisation of dissolved amino acids indicates rapid modification of organic matter in the benthic boundary layer. Mar Ecol Prog Ser 156:43-50

Rowe GT, Deming JW (1985) The role of bacteria in the turnover of organic carbon in deep-sea sediments. J Mar Res 43:925-950

Sanchez-Cabeza JA (1996) Radiotracers in the North-Balearic basin. In: Canals M, Casamor JL, Cacho I, Calafat A, Monaco A (eds) EUROMARGE-NB Final report, MAST Ir Programme, EC, Vol 2, p 150-168

Smith KL Jr, Kaufmann RS, Baldwin RJ (1994) Coupling of near-bottom pelagic and benthic processes at abyssal depths in the eastern North Pacific ocean. Limnol Oceanogr 39:1101-1118

Talbot V, Bianchi $M$ (1997) Bacterial proteolytic activity in sediments of the Subantarctic Indian Ocean Sector. Deep Sea Res II 44:1069-1084

Turley CM, Lochte K (1990) Microbial response to the input of fresh detritus to the deep-sea bed. Palaeogeogr Palaeoclimatol Palaeoecol 89:3-23

Turley CM, Lochte K, Lampitt RS (1995) Transformations of biogenic particles during sedimentation in the northeastern Atlantic. Phil Trans R Soc Lond B 348:179-189

Turley CM, Mackie PJ (1994) Biogeochemical significance of attached and free-living bacteria and the flux of particles in the NE Atlantic Ocean. Mar Ecol Prog Ser 115:191-203

Turley CM, Mackie PJ (1995) Bacterial and cyanobacterial flux to the deep NE Atlantic on sedimenting particles. Deep Sea Res 1 42:1453-1474

Turley CM, Taylor A, Harris JRW, Ruddy G, Stutt E, Course P (1996) Bacterial biomass and production in seawater and on particles and modelling their role in carbon flux. In: Bianchi $M$ (ed) European microbiology of particulate sytems. Final report MAST II Programme, EC, Vol 2, contr no. 5, p 1-25

Yoro SC, Sempéré $R$, Turley $C$, Unanue MA, Durieu de Madron X. Bianchi M (1997) Cross-slope variations of organic carbon and bacteria in the Gulf of Lions in relation to water dynamics (northwestern Mediterranean). Mar Ecol Prog Ser 161:255-264

Submitted: January 5, 1998; Accepted: April 7, 1998 Proofs received from author(s): June 9, 1998 